\title{
The role of exoticism in
}

\section{international contemporary art} in the era of globalization - an empirical study of international art magazines from I97I to 2010

\author{
I O papel do exotismo na arte contemporânea internacional na era da globalização \\ - um estudo empírico das revistas internacionais de arte de I97I a 2010
}

\section{Kusuk Yun ${ }^{\mathrm{I}}$}

RESUMO - Na era da globalização, a visibilidade dos artistas não ocidentais tornou-se cada vez mais importante. Ao tentar melhorar a diversidade global e o relativismo cultural, surgiu uma forma cultural autêntica. Como resultado, os artistas periféricos podem ser tentados a representar a própria identidade cultural como um novo valor estético, mas através de uma imagem estereotipada adaptada ao gosto ocidental. Através do estudo de artigos sobre artistas japoneses, chineses e coreanos publicados em revistas internacionais de arte, analisaremos o crescimento de sua visibilidade e o desenvolvimento de clichês e estereótipos em relação a eles. Pretendemos descobrir se o sentimento de exotismo gerado pelos meios de comunicação de massa, através da transmissão de imagens estereotipadas, desempenha um papel importante na determinação da visibilidade dos países não ocidentais na arte contemporânea internacional. PALAVRAS-CHAVE-Globalização;

\begin{abstract}
internacionalismo; território; exotismo; critério estético. ABSTRACT · In the era of globalization, the visibility of non-Western artists has become more and more important. In trying to enhance global diversity and cultural relativism, an exotic cultural form has emerged. As a result, peripheral artists can be tempted to represent their own cultural identity as a new esthetic value, but through a stereotyped image suited to Western tastes. Through the study of articles about Japanese, Chinese, and Korean artists published in international art magazines, we will look at the growth in their visibility and the development of clichés and stereotypes toward them. We will aim to discover whether a sense of exoticism generated by the mass-media, by broadcasting stereotyped images, plays an important role in determining the visibility of non-Western countries in international contemporary art. KEYWORDS - Globalization; internationalism; territory; exoticism; esthetic criterion.
\end{abstract}

Recebido em 30 de setembro de 2017

Aprovado em 6 de fevereiro de 2018

YUN, Kusuk. The role of exoticism in international contemporary art in the era of globalization an empirical study of international art magazines from I97I to 20Io. Revista do Instituto de Estudos Brasileiros, Brasil, n. 69, p. 362-388, abr. 2018.

DOI: http://dx.doi.org/Io.II606/issn.23I6-90IX.voi69p362-388

I Université Paris VIII (Vincennes, Saint-Denis, France). 
If the discourse of modern art was formed from a universal artistic language combining both the central art schools and colonies ${ }^{2}$, contemporary art can be characterized by pluralism, for instance via the extensive participation of foreign artists in international exhibitions in Western countries? ${ }^{3}$ Notably, the exhibition Magicians of the Earth, organized simultaneously in 1989 by Jean-Hubert Martin at the Pompidou Center and the Grande Halle at the Parc de la Villette, shows a strong awareness of the territorial and esthetic problematic imposed by the multicultural approach through its promotion of the notion of homogenization. This was the first time that artists from different continents of the World displayed work in the same place without "suffering discrimination"4.

However, many critics railed against this pluralist exhibition, as they believed

2 Note that Modern art can be characterized by the terms "currents (courants)" and "schools (écoles)": impressionism. fauvism. cubism. surrealism. abstraction. etc. (HEINICH, N. Pour en finir avec la querelle de l'art contemporain. Paris: L’Echoppe. I999.). Without regard to their nationality. numerous modern artists contributed to the foundation of those artistic orientations by generating the notion of "unicism" and cultural hegemony (see the text of Thomas McEvilley in the catalogue of Magicians of the Earth). while contemporary art has valorized cultural. geographical. and ethnic diversity since the era of globalization.

3 GUILBAUD, S. Comment New York vola l'idée d'art moderne: expressionnisme abstrait. liberté et guerre froide. Nîmes: Jaqueline Chambon, I998, p. 223; MOTHERWELL, R. I4 Americans. Dorothy Miller. MOMA. New York, I946. A sort of "unicism" wherein immigrants and foreign artists developed their style. André Warnod, inventor of the term "School of Paris", considered this unicism to be a "bastardization" of French culture and its art. This contemporary internationalism (foundation of the colonies of foreign artists who work in the same direction according to André Warnod) is different from universalism and materialized at around the end of the Second World War. Formalism, invented by American painters, abandoned the idea of national art in favor of provincial art, as well as political and figurative art, in the I930s. This formalistic universalism appears frequently in Motherwell's discourse. He wrote: 'Art has no country. Just to be an American or French painter is to be nothing.'

4 Organized in 1989 by Jean-Hubert Martin, Magicians of the Earth brought together IoI contemporary artists from non-Western territories: Asia, Far East, Africa, Latin America, Oceania, etc. In the catalogue of this exhibition, the curator emphasizes the importance of "homogenization" pluralism. MARTIN, J-H. Magiciens de la Terre (catalogue of exhibition). Paris: Musée National d’Art Contemporain, I989. 
the selection of works was made from the viewpoint of a Western audience, thereby reducing the landscape of the world to a tourist vision dreamt-up by the media ${ }^{5}$. Regarding this new phenomenon, which acts as a kind of cultural prism, Boris Groys notes:

The unity of an international artistic language and purely artistic creation has been replaced in our time by a unified mass-media network, which, like international tourism, has a vested interest in the regional and specific but not in the actual reality of regional problems, movements, interests, etc. Instead, this network is looking for specific codes that distinguish a given place from all others on the international tourist map: pyramids in Egypt; Hitler in Germany; Stalin and perestroika in Russia; penguins and environmental protection in the Antarctic, etc. An original national art is required to formulate itself around easily recognizable international signs 6 .

The "specific codes" mentioned by Groys act today as a mechanism or universal language through which the Western world can understand the works of non-Western artists?. Here, we are interested in peripheral artists whose visibility has increased steadily on the international contemporary art scene. As we will see, these artists appear to be adapting their works according to a set of global norms determined by Western tastes, while playing into stereotypes and clichés that give a sense of exoticism. This problematic manifests in almost the same context as Primitivism in 2oth Century Art: Affinity of the Tribal and the Modern, another pioneer of pluralist exhibition organized in 1985 at MoMA. Treating tribal objects as art means, this exhibition ignores, according to James Clifford, their cultural context by developing an aesthetic and anthropologic approach. In this object system, a tribal piece can circulate in the art world as a "masterpiece", a term invented by West and universally

5 When organizing the exhibition Magicians of the Earth, Jean-Hubert Martin relied on (Western) perception, knowledge and taste. Yves Michaud criticizes this reliance, because the principal curator has only retained, in his choice of works, "our aesthetic categories and criteria" and this "confirms" and "reinforces" our postmodern belief in "diversity" and "the force of creation". See chapter II of the book: Michaud, Y. 2007. L'artiste et les commissaires.

6 GROYS, B. The Global Issue: a symposium. Art in America, New York, July I989, p. 87-88; MICHAUD, Y. L'artiste et les commissaires: quatre essais non pas sur l'art contemporain mais sur ceux qui s'en occupent. Paris: Hachette Littératures, 2007, p. 86-87. (collection Pluriel).

7 Our research develops an important liaison with criticism of the exhibition. However, we would like to underscore the esthetic relativism linked to the hedonism and "cultural satisfaction" of the capitalist system. Note that many critics reacted to this pluralist exhibition, which inspires even today many international exhibitions and academic articles. The Pompidou Center gives today a list of critics containing more than I30 citations (!) under the title of "FORTUNE CRITIQUE DE L'EXPOSITION MAGICIENS DE LA TERRE BIBLIOGRAPHIE SÉLECTIVE». [Online] Available from: https://www.centrepompidou.fr/media/document /76/oc/760c508854506430ofdr3242e9332aco/normal.pdf. 
recognizable ${ }^{8}$. Note that after Magicians of the Earth and Primitivism in $20^{\text {th }}$ Century Art, many international exhibitions organized in Western countries underscore the importance of cultural specificity and the "exotic" aspects of non-Western countries. Representative examples include: Sharing Exoticisms, $5^{\text {th }}$ Lyon Biennale (2000); Documenta II (2002) directed by Okwui Enwezor; J'aime Chéri Samba, Cartier Foundation (2004); and Africa Remix, Pompidou Center (2005).

Note that all of the above exhibitions referenced above ran after the I980s, which gives the impression that this period was a turning point in the history of exhibitions. For our study, we indeed consider the beginning of globalization to have been around the I980s'. We would like to investigate how to understand these international exhibitions and the development of non-Western artists in regard to the problematic raised by the question of exoticism, a result of globalization.

In contemporary art, the notion of exoticism reveals a particularly ethnocentric attitude that distinguishes between the central and the marginal. While studying, at the beginning of the 20oos, the major French public collections, selections of major institutions, the Kunstkompass, international contemporary art fairs, biennials, and contemporary art auctions, Alain Quemin noted that a few countries like the USA, Germany, and the UK - all located in the Western part of the world - dominated the contemporary art world, while non-Western countries were still dominated or almost invisible ${ }^{\text {Io }}$. The question of "The Illusion of the Abolition of Boundaries in the International Contemporary Art World” emerges, denying both globalization and

8 CLIFFORD, J. The predicament of culture: twentieth-century ethnography. literature. and art. Cambridge: Harvard University Press, I988, p. I89-2I4. Note that the place of non-Western artists is more and more important today. The new permanent exhibition entitled Modernités plurielles: de I905 à I970 is a fruit of pluralist reflection allowing non-Western modern artists an opportunity to integrate into a history of art formerly determined exclusively by the West. This de-contextualization and revision of the canon generate also an important problematic in the studies of Béatrice Joyeux-Prunel and Ana Paula Cavalcanti Simioni, who emphasize the significant role and visibility of non-Western artists in the development of the avant-garde. Despite these important examples, however, we would like to limit our interest to contemporary non-Western artists.

9 As our study investigates the problematic created by the media, it is worthwhile to point out the question of diffusion and representation which can be crystalized by the term "exhibition" in the field of contemporary art. With many exhibitions devoted to non-Western artists, it is possible to say that globalization starts from I980s, even if many non-Western artists - including Nam June Paik, Marina Abramović, Yoko On, On Kawara, Sarkis, and Ilia Kabakov - gained early international reputations during the I96os and I970s. This viewpoint can be further consolidated if we consider four international art magazines we have selected displaying, we will see, a large increase in the visibility of Asian artists from I980. Recall also that the Uruguay Round took place from I986 to I994, resulting in the French term "cultural exception", which has today been replaced by “cultural diversity”.

IO QUEMIN, A. L'illusion de l'abolition des frontières dans le monde de l'art contemporain international: La place des pays “périphériques» à "l’ère de la globalisation et du métissage». Paris: Université de Marne-la-Vallée, 2002. 
the blending of cultures that had promised, in theory, a horizontal view between countries and continents ever since the exhibition Magicians of the World ${ }^{\mathrm{II}}$.

Despite their low profile, some peripheral countries have made their presence known in the international contemporary art scene. Analyzing the country of birth and residence of international artists, Alain Quemin notes, 'As we see, the exoticism that seems to attract new artists from outside of the Western world is largely promoted by institutions of the Western world which continue to act as "gatekeepers" "ז.' Non-Western artists can now benefit from a - partial - legitimate recognition in the West, via their differences.

We wonder then if exoticism, generated by cliché and stereotype, acts as an aesthetic criterion in the contemporary art world, allowing peripheral artists to be more easily discovered by the Western world.

In order to understand the role of exoticism in contemporary art, we propose two different analytic approaches related to understanding the circulation of artwork with regard to its diffusion and creation. The first approach is interested in the character of mass-media, which engenders cliché and stereotype through repetition, and involves empirical research into articles and critics devoted to non-Western artists. While this approach is principally based on the question of communication and its development in a mass-media society, our second approach focus on the artist's creative attitude. If we consider visibility as synonymous with success, entailing social, political, and economic power ${ }^{\mathrm{I}}$, it's on point to say that the artist - now a quasi-star ${ }^{\mathrm{I}}$ - aspires to reach the summit of visibility and reputation in the international art stage through her creation. As a result, the artist may try to adapt, adjust, and standardize their creation to the norms imposed by the mass-media and Western taste. For this work, we look at several artists' speeches, statements, and texts representing their attitude toward and motif of creation. Before delving deeper into our study, however, we would like to clearly describe the target of our research.

\section{METHOD AND TARGET OF STUDY}

How do we identify the stereotyped images formed by the mass-media that circulate in the art world? There are a number of forms of communication that we include under the umbrella of "mass-media". If we think of contemporary art as characterized by the discourse and concepts of the many art movements born in the I960s, such as

II Ibidem; Quemin, A. L'art contemporain international: entre les institutions et le marché. Paris: 2002; QUEMIN,

A. La Chine et l'art contemporain: l'arrivée de l'Empire du Milieu dans le monde et sur le marché de l'art. In: BRET, J.-N. et MOUREAU, N. (Dir.). L'art. l'argent et la mondialisation. Paris: L'Harmattan, 20I3; QUEMIN, A. Les Stars de l'art contemporain. Paris: CNRS 20I3; HEST, V. F. Territorial factors in a globalisedart word? The visibility of countries in international contemporary art events. Rotterdam: ERMeCC, 2012.

I2 QUEMIN, A. Le rôle des pays prescripteurs sur le marché et dans le monde de l'art contemporain. Paris: Rapport au ministère des affaires étrangères, 200I, p. пाо.

I3 HEINICH, N. De la visibilité: Excellence et singularité en régime médiatique. Paris: Gallimard, 2012.

I4 QUEMIN, A. Les stars de l'art contemporain, op. cit. 
conceptual art, minimal art, arte povera, Fluxus, feminist art, etc., it is most helpful to look at articles giving artists' ideas or critics' opinions about the work of "exotic" artists as elements of mass-media. Many galleries otherwise distribute, we will see, articles published in art magazines through their websites to represent the work of the artists supported by them. Since the I970s, Western art magazines such as Art in America (US), Artforum (US), Flash Art (IT) and Artpress (FR) have gradually become interested in peripheral artists and territories ${ }^{15}$. Note that all four of these magazines have progressively expanded the geography of contemporary art: Art in America has been interested in the artistic activities organized in the USA and Europe since the I960s and has discovered more and more continents and countries from the I970s onwards ${ }^{16}$. Flash Art and Artpress gained the label "international" during the I970s by communicating with many countries and publishing editions in Italian (Flash Art), French (Artpress), and English ${ }^{17}$. As for Artforum, during the I980s this periodical turned toward countries such as the UK, Germany, Belgium, Canada, and Japan as seen in the Review rubric. We note that all of these magazines, except Artpress, are referenced by Kunstkompass, a publication read by the most influential economic and cultural figures of the art world ${ }^{\mathrm{I}}$. As for Artpress, this periodical is considered 'one of the best international magazines in contemporary art, following creativity closely, while providing key analysis of a domain that raises at the same time a lot of curiosity and debate ${ }^{\mathrm{I9}}$.' Therefore, we can safely describe these four art journals as influential and representative "international contemporary art magazines".

Given the vast influence of these four periodicals, as well as their recognition by both professionals and laymen, we decided to study them as research objects.

I5 If we look at only the Japanese, Chinese, and Korean artists presented in our four art magazines in the mid-I970s, we find many international artists like Susaku Arakawa, On kawara, Isamu Noguchi, Nam June Paik, Yoko Ono, etc. As for peripheral territories, note that the territories of contemporary art become noticeably wider from the I970s in the Review/Preview rubric of our four international art magazines: I970s: I4 countries, I980s: 32 countries, I990s: 54 countries, 2000s: 69 countries.

I6 Note in particular that these four art magazines were able to participate in the evolution of contemporary art due to the date of their foundation. Published since I9I3, Art in America was an art magazine devoted to classical art until the early I950s. In I96I, it presented Yves Klein, Raymond Hains, Jacques de Villeglé, Arman, and other French pioneers of contemporary art through the article Paris letter: New realists. The other international periodicals were founded in the I960s and I970s: Artforum (I962), Flash Art (1967), and Artpress (I97I).

I7 To be precise, Flash Art adopted its bilingual system (EN/IT) from issue number I7 (April/March), published in I970, while Artpress became interested in English from the 80s after its new editor, Louis Dalmas, gave it the title Artpress international. Note that this French magazine developed its international style before being baptized with the term "international". From I973, it was already publishing articles on the current state of art in several European countries.

I8 MOULIN, R. L'artiste, l'institution et le marché. Paris: Flammarion, I997, p. 77-80. According to Raymonde Moulin, among attempts to evaluate aesthetic value as a basis of financial forecasting, the most sophisticated is that of the Kunstkompass.

I9 MILLET, C. D'art press à Catherine M. Entretiens avec Richard Leydier. Paris: Gallimard, 2011. 
We looked at the period of 40 years from I97I to 2010 for a retrospective, decade by decade, view of the evolution of cultural clichés surrounding peripheral artists and the number of articles devoted to them. We recall that contemporary art grew quickly in the I970s, following the seminal exhibition When attitudes become form ${ }^{20}$ organized in 1969 by Harald Szeemann at the Kunsthalle in Berne, which featured artists from 36 different countries ${ }^{2 \mathrm{I}}$. It is clear, therefore, that contemporary art has been, since its birth, a very open field to artists from around the world.

As the so-called "peripheral countries" are too numerous ${ }^{22}$, it is necessary to focus our research on a few specific countries. Japan, South Korea (below Korea), and China are the best choices, in our view, because they are very active on the international art scene. Japanese artists have played an important role in the contemporary art world since the I950s through artistic movements such as Gutai and Mono-ha. The generation of Japanese Pop Art is also very important and has had a substantial influence on international institutions and art markets. For Korea, Nam June Paik is recognized as a figurehead of contemporary art and as the founder of video art. Also, Jehon Soo-cheon, Kang Ik-joong, and Lee Bul earned Special Mentions in the I990s and Im Heung-soon won the Silver Lion at the Venice Biennale in 20I5. Furthermore, Cho Min-suk notably won the Golden Lion at the Venice Biennale of Architecture in 20I4. China, which has seen great economic expansion since the I99os and today even excels Japan economically, now has numerous artists experiencing real success on the international stage and in the art market, including Cai Guo-Qiang, Ai Wei Wei, Zhang Yuan, Zeng Fanzhi, Yue Minjun, Zhang Xiaogang, and Mu Boyan ${ }^{23}$.

These three countries have much in common, not only in regard to their geographical, political, and historical contexts but also in terms of their culture. All three adopted Buddhism and Confucianism as philosophical and religious ideologies many years ago, much as Europe adopted Christianity from the end of the Roman Empire. Japan, China, and Korea are also all economically highly developed and very sensitive to globalization today. The only difference between the artistic creations of these three countries may be a simple matter of form and of material appearance, as suggests Achille Bonito Oliva, who, in I995, organized Asiana: Contemporary Art Far

20 Note that art professionals (curators, critics, etc.) consider contemporary art to have emerged and developed during the I970s after the seminal exhibition When Attitudes Become Form, organized by Harald Szeemann in 1969 in Bern, while art historians think that it began to develop after I945. (QUEMIN, A. Les Stars de l'art contemporain, op. cit. p. I3-I7; QUEMIN, A. L'art contemporain international..., op. cit., p. I5-I8; MILLET, C. L'Art contemporain: Histoire et géographie. Paris: Flammarion, 2006; HEINICH, N. Pour en finir..., op. cit.; GLICENSTEIN, J. L'art: une histoire d'expositions. Paris: Presses Universitaires de France, 2009.)

2I France, UK, Belgium, Netherlands, Switzerland, Spain, Monaco, Italy, Denmark, Norway, Austria, Poland, Greece, Czech Republic, Romania, Latvia, Hungary, USA, Iran, Turkey, Tunisia, Egypt, Cuba, Algeria, Lebanon, Brazil, Lithuania, Argentina, Chile, Ukraine, Russia, Morocco, China, Japan, Vietnam, and Indonesia.

22 Note that we today count 193 member states within the UN.

23 As for the development of the visibility of Japanese, Chinese and Korean artists in the art market, consult the Art Market Annual Report offered by Artprice. 
East at the Palazzo Vendramin Calergi, an exhibition dedicated to Japanese, Chinese, and Korean artists ${ }^{24}$.

In this study, we analyze our topic by looking at the growth in visibility of artists from these three East Asian countries in our four international magazines (Art in America, Artforum, Flash Art, and Artpress). In order to expand our scope of interest, however, our study also contains a brief consideration of the visibility of Latin American countries and their artists. We then analyze the clichés and stereotypes that can be found amongst the articles devoted to Asian artists from the countries we have chosen.

\section{CONSIDERATION OF CLICHÉ AND STEREOTYPE}

Here we will attempt to clarify and define the meaning of the terms "cliché" and "stereotype" that we employ throughout our study. During our research, we gathered I,445 articles from our four international art magazines. As such, the analysis of all this information was a huge undertaking that required a systematic approach that included a categorizing of cliché and stereotype based on re-defined and re-examined meanings.

We found the definitions of "cliché" and "stereotype" proposed by Jean-Marc Moura, professor of literature at the University Paris Ouest Nanterre La Défense, to be especially influential. Moura asserts that stereotype can be defined as 'a preconceived idea, an exaggerated belief associated with a category' and cliché as 'stylistic defined as an effect of fixed style by the custom and a manifestation of a servile spirit of imitation 25 .

With these definitions in place, all of the articles we looked at could be sorted effectively into several categories according to the types of preconceptions, prejudices, and empirical conceptions they exhibit in response to the question: Does this article contain cliché and stereotype? To simplify our research, however, here we directly consider only three examples of articles that can be framed by three types of contextualization, utilizing the terms "preconception", "exaggeration", "fixed style", and "imitation".

24 OLIVA, A. B.; GU, D.; MAGGIO, G. D.; FEI, D.; KIM, S.-D. Asiana: Contemporay Art from Far East: Edited on the occasion of the exhibition at the Palazzo Vendramin Calergi. Milan: Fondazione Mudima in cooperation with Venice Municipality the Cultural Council,, I995, p. 7.

25 MOURA, J.-M. La littérature des lointains: Histoire de l'exotisme européen au XX siècle. Paris: Honoré Champion, I998. 


\section{INTERPRETATIVE CONTEXTUALIZATION}

- Presentation of the artist Kim Whanki

You use Chinese materials in your work, such as Chinese medicinal herbs and rice paper. Are you consciously trying to continue a tradition? You also practice some 'violent' actions, such as absorbing blood from your own veins, using the skins of freshly killed animals. Are these examples of the indifference to contradiction and violence in Buddhist and Zen thought? ${ }^{26}$.

The passage cited above, from an article devoted to the Korean artist Kim Whanki, can be understood in two dimensions. The first is that Kim uses several different materials associated with Asian tradition, which then introduces an "exotic" perfume through its appearance and cultural context. The second is the viewpoint of the interlocutor attempting to understand the given subject through a cultural and religious approach to Asia. In this article, we find in the end a "stylistic" character in the question of material and "preconception" in the question of the journalist.

\section{GeOgRaPhical CONTEXTUALIZATION}

- Presentation of the artist Isamu Noguchi

... Noguchi takes aspects of traditional Japanese gardens, and aspects of Surrealist space, and makes them into something neither European nor Japanese. [...] While finished in the Western sense, the complexity in Noguchi's work of the last 20 years expresses an Eastern sensibility in its seeming roughness and irregularity, and in the spiritual meaning he gives to the working of stone ${ }^{27}$.

In the above passage, from an article devoted to the Japanese artist Isamu Noguchi, we focus on geographic distinctions, noting that our problematic is essentially based on the comparison of different territories engaged in the development of contemporary art. The terms "European", “Japanese”, and "Eastern" lend themselves to this type of geographical conception, which then can act as a source of inspiration for the empire of cliché and stereotype through the creation of a new logical system: "the traditional Japanese garden". This geographical taxonomy contributes, with its cultural context and expectation, to the foundation of cultural specificity and comparison to other territories: Europe and the West. For this reason, we consider this territorial aspect to be a form of cliché and stereotype.

26 Flash Art, I993, oct., p. 65.

27 Artforum, I980, apr., p. 53. 


\section{HISTORICAL AND POLITICAL CONTEXTUALIZATION}

- Presentation of the artist Yukinori Yanagi

In the more effective work of the two presented at the Queens Museum, The Forbidden Box (I995), two superimpose I7-foot-tall voile panels printed with the image of an atomic cloud hung above an open lead box inscribed with the name of the bomb dropped on Hiroshima, 'Little Boy'. [...] The mushroom-cloud images were as faded as old film footage, the words like off-register newspaper type ${ }^{28}$.

During our study of our four international art magazines, we noticed that the three Asian countries we chose were often characterized according to their historical and political context. The terms "Mao" and "Cultural Revolution" appeared repeatedly in our international art magazines only for Chinese artists. In the same way, "Hiroshima" and "mushroom-cloud", also highly recurrent terms in our magazines, function as characterizations according to the historical context and specificity of Japan. We note that it is not only the mass-media that elaborate on these types of stylistic expressions but also the artists themselves. We moreover see that, as the previous section describes, the artists refer strongly to the history and political situation of their country as forms of artistic inspiration for them. We believe in fact that this artistic approach, linked as it is to "real-world" events, is intended to garner the interest of Western audiences in international contemporary art.

In addition to the above three types of articles, we also consider usage of the names of the ancient dynasties, countries, or civilizations - like "Heian", "Meiji", "Han", "Tang", and "Ming" - to be forms of cliché and stereotype, if these terms are used repeatedly or overly emphasized in a text. We do the same for the valorization of Asian languages like "Yano", "Ikegaya”, "Sumi", "Nihon-ga”, etc. ${ }^{29}$.

28 Art in America, oct., I995, p. II6-II7 and I38.

29 Note that the mention of ancient empires and the valorization of foreign languages can be understood through the concept of the "lexical artifice" proposed by Jean-Marc Moura (MOURA, J.M. La littérature des lointains..., op. cit., p. 98-Ioo). 


\begin{tabular}{|c|c|c|c|c|c|c|c|c|c|c|c|c|c|c|c|}
\hline \multicolumn{5}{|c|}{ Rang } & \multirow[b]{2}{*}{ Pays } & \multicolumn{5}{|c|}{ Nombre d'articles } & \multicolumn{5}{|c|}{$\%$} \\
\hline \multirow[t]{2}{*}{$\begin{array}{l}1971- \\
1980\end{array}$} & \begin{tabular}{|l|}
$1981-$ \\
1990 \\
\end{tabular} & \begin{tabular}{|l|}
$1991-$ \\
2000 \\
\end{tabular} & \begin{tabular}{|l|}
$2001-$ \\
2010 \\
\end{tabular} & \begin{tabular}{|l|}
$1971-$ \\
2010 \\
\end{tabular} & & \begin{tabular}{|l|}
$1971-$ \\
1980 \\
\end{tabular} & \begin{tabular}{|l}
$1981-$ \\
1990 \\
\end{tabular} & \begin{tabular}{|l|}
$1991-$ \\
2000 \\
\end{tabular} & \begin{tabular}{|l|}
2001 \\
2010 \\
\end{tabular} & \begin{tabular}{|l}
$1971-$ \\
2010 \\
\end{tabular} & \begin{tabular}{|l|}
$1971-$ \\
1980 \\
\end{tabular} & \begin{tabular}{|l|}
$1981-$ \\
1990 \\
\end{tabular} & \begin{tabular}{|l|}
$1991-$ \\
2000 \\
\end{tabular} & \begin{tabular}{|c|}
$2001-$ \\
2010 \\
\end{tabular} & $\begin{array}{l}1971- \\
2010\end{array}$ \\
\hline & & & & & Art in America & & & & & & & & & & \\
\hline 1 & 1 & 1 & 1 & 1 & USA & 1018 & 2480 & 2084 & 3319 & 8901 & 25,23 & 97,29 & 90,45 & 89,29 & 92,34 \\
\hline 4 & 2 & 2 & 2 & 2 & UK & 12 & 30 & 39 & 76 & 157 & 1.12 & 1,18 & 1,69 & 2,04 & 1.63 \\
\hline 3 & 4 & 3 & 4 & 3 & France & 14 & 9 & 38 & 56 & 117 & 1.31 & 0.35 & 1.65 & 1.51 & 1.21 \\
\hline 5 & 5 & 4 & 3 & 4 & Germany & 3 & 7 & 27 & 71 & 108 & 0.28 & 0.27 & 1.17 & 1.91 & 1.12 \\
\hline 0 & 0 & 9 & 5 & 6 & Italy & 0 & 0 & 7 & 38 & 45 & 0.00 & 0.00 & 0.30 & 1.02 & 0.47 \\
\hline 6 & 7 & 5 & 9 & 7 & Nederland & 2 & 1 & 24 & 15 & 42 & 0.19 & 0,04 & 1.04 & 0.40 & 0.44 \\
\hline 8 & 7 & 10 & 6 & 8 & Swiss & 1 & 1 & 6 & 28 & 36 & 0.09 & 0,04 & 0.26 & 0.75 & 0.37 \\
\hline 2 & 6 & 10 & 12 & 9 & Canada & 16 & 5 & 6 & 8 & 35 & 1.50 & 0.20 & 0.26 & 0,22 & 0.36 \\
\hline 6 & 0 & 7 & 7 & 10 & Spain & 2 & 0 & 13 & 17 & 32 & 0,19 & 0.00 & 0.56 & 0.46 & 0.33 \\
\hline 0 & 3 & 5 & 7 & 5 & Japan & 0 & 13 & 24 & 17 & 54 & 0.00 & 0.51 & 1.04 & 0.46 & 0.56 \\
\hline 0 & 0 & 0 & 12 & 14 & China & 0 & 0 & 0 & 8 & 8 & 0.00 & 0.00 & 0.00 & 0.22 & 0,08 \\
\hline \multirow[t]{4}{*}{0} & \multirow[t]{2}{*}{0} & 14 & 17 & 18 & South Korea & 0 & 0 & 2 & 3 & 5 & 0.00 & 0.00 & 0.09 & 0.08 & 0.05 \\
\hline & & & & & Other 29 countries & 1 & 3 & 34 & 61 & 99 & 0.09 & 0.12 & 1.49 & 1.64 & 1.04 \\
\hline & \multirow[t]{2}{*}{-} & - & - & - & Total & 1069 & 2549 & 2304 & 3717 & 9639 & 100 & 100 & 100 & 100 & 100 \\
\hline & & & & & Artforum & & & & & & & & & & \\
\hline 1 & 1 & 1 & 1 & 1 & USA & 1583 & 2677 & 2142 & 4243 & 10645 & 97,78 & 73,10 & 56,89 & 64,91 & 68,31 \\
\hline 5 & 2 & 2 & 2 & 2 & Germany & 2 & 220 & 308 & 408 & 938 & 0,12 & 6,01 & 8,18 & 6,24 & 6,02 \\
\hline 2 & 4 & 5 & 3 & 3 & UK & 13 & 126 & 208 & 385 & 732 & 0,80 & 3,44 & 5,52 & 5,89 & 4,70 \\
\hline 6 & 5 & 3 & 4 & 4 & France & 1 & 110 & 216 & 270 & 597 & 0,06 & 3,00 & 5,74 & 4,13 & 3,83 \\
\hline 3 & 3 & 3 & 6 & 5 & Italy & 12 & 169 & 217 & 174 & 572 & 0,74 & 4,61 & 5,76 & 2,66 & 3,67 \\
\hline 0 & 7 & 7 & 5 & 6 & Swiss & 0 & 70 & 93 & 175 & 338 & 0,00 & 1,91 & 2,47 & 2,68 & 2,17 \\
\hline 6 & 8 & 6 & 7 & 7 & Spain & 1 & 42 & 113 & 123 & 279 & 0,06 & 1,15 & 3,00 & 1,88 & 1.79 \\
\hline 6 & 6 & 9 & 10 & 8 & Canada & 1 & 82 & 76 & 59 & 218 & 0,06 & 2,24 & 2,02 & 0,90 & 1,40 \\
\hline 0 & 11 & 8 & 8 & 2 & Austria & 0 & 22 & 90 & 105 & 217 & 0,00 & 0,60 & 2.39 & 1,61 & 1,39 \\
\hline 4 & 9 & 10 & 9 & 10 & Nederland & 4 & 35 & 41 & 66 & 146 & 0,25 & 0,96 & 1,09 & 1,01 & 0,94 \\
\hline 0 & 13 & 16 & 17 & 16 & Japan & 0 & 19 & 14 & 25 & 58 & 0,00 & 0.52 & 0,37 & 0,38 & 0,37 \\
\hline 0 & 0 & 21 & 20 & 21 & South Korea & 0 & 0 & 7 & 17 & 24 & 0,00 & 0,00 & 0,19 & 0,26 & 0,15 \\
\hline \multirow[t]{19}{*}{0} & 0 & 32 & 19 & 23 & China & 0 & 0 & 1 & 19 & 20 & 0,00 & 0,00 & 0,03 & 0,29 & 0,13 \\
\hline & & & & & Other 40 countries & 2 & 90 & 239 & 468 & 799 & 0,13 & 2,46 & 6,35 & 7,16 & 5.13 \\
\hline & & & & & Total & 1619 & 3662 & 3765 & 6537 & 15583 & 100 & 100 & 100 & 100 & 100 \\
\hline & & & & & Flash Art & & & & & & & & & & \\
\hline & 1 & 1 & 1 & 1 & USA & & 659 & 495 & 659 & 1813 & & 54,33 & 31,09 & 37.19 & 39,61 \\
\hline & 3 & 4 & 2 & 2 & UK & & 123 & 163 & 291 & 577 & & 10,14 & 10,24 & 16,42 & 12,61 \\
\hline & 4 & 2 & 3 & 3 & Germany & & 87 & 254 & 176 & 517 & & 7,17 & 15,25 & 2,23 & 11,30 \\
\hline & 2 & 3 & 4 & 4 & France & & 218 & 188 & 106 & 512 & & 17.97 & 11,81 & 5.98 & 11.19 \\
\hline & 5 & 5 & 5 & 5 & Italy & & 26 & 70 & 93 & 189 & & 2,14 & 4.40 & 5.25 & 4.13 \\
\hline & 8 & 6 & 6 & 6 & Swiss & & 14 & 55 & 47 & 116 & & 1.15 & 3.45 & 2.65 & 2.53 \\
\hline & 6 & 7 & 9 & 7 & Astria & & 19 & 50 & 30 & 99 & & 1.57 & 3.14 & 1.69 & 2.16 \\
\hline & 8 & 8 & 10 & 9 & Spain & & 14 & 48 & 25 & 87 & & 1.15 & 3.02 & 1.41 & 1.90 \\
\hline & 7 & 12 & 8 & 10 & Nederland & & 15 & 37 & 33 & 85 & & 1,24 & 2.32 & 1.86 & 1.86 \\
\hline & 10 & 9 & 7 & 8 & Japan & & 11 & 42 & 44 & 97 & & 0.91 & 2,64 & 2,48 & 2.12 \\
\hline & 0 & 0 & 17 & 22 & China & & 0 & 0 & 12 & 12 & & 0.00 & 0,00 & 0.68 & 0.26 \\
\hline & 0 & 24 & 32 & 32 & South Korea & & 0 & 2 & 3 & 5 & & 0,00 & 0,13 & 0,17 & 0,11 \\
\hline & & & & & Other 46 countries & 0 & 27 & 188 & 253 & 468 & & 2.23 & 11.81 & 14.29 & 10.22 \\
\hline & & & & & & & 1213 & 1592 & 1772 & 4577 & & 100 & 100 & 100 & 100 \\
\hline & & & & & Artpress & & & & & & & & & & \\
\hline 1 & 1 & 1 & 1 & 1 & France & 538 & 2764 & 2482 & 2104 & 7888 & 63,07 & 78,63 & 76,87 & 68,98 & 74.07 \\
\hline 7 & 3 & 2 & 3 & 2 & USA & 13 & 119 & 231 & 172 & 535 & 1.52 & 3.39 & 7,06 & 5.64 & 5,02 \\
\hline 2 & 2 & 4 & 5 & 3 & Swiss & 202 & 183 & 68 & 80 & 533 & 23,68 & 5,21 & 2,11 & 2,62 & 5,00 \\
\hline 5 & 5 & 6 & 2 & 4 & UK & 22 & 101 & 46 & 207 & 376 & 2,58 & 2,87 & 1,42 & 6,79 & 3.53 \\
\hline 6 & 4 & 3 & 6 & 5 & Belgium & 18 & 116 & 112 & 69 & 315 & 2,11 & 3.30 & 3,47 & 2,26 & 2,96 \\
\hline 3 & 7 & 7 & 4 & 6 & Sapin & 27 & 33 & 41 & 103 & 204 & 3,17 & 0,94 & 1,27 & 3,38 & 1,92 \\
\hline 4 & 6 & 9 & 2 & 7 & Nederland & 25 & 87 & 31 & 28 & 171 & 2,93 & 2,48 & 0,96 & 0,92 & 1,61 \\
\hline 0 & 8 & 5 & 8 & 8 & Sapin & 0 & 32 & 61 & 49 & 142 & 0,00 & 0,91 & 1.89 & 1,61 & 1,33 \\
\hline 8 & 2 & 8 & 7 & 2 & Italy & 5 & 26 & 40 & 55 & 126 & 0.59 & 0,74 & 1.24 & 1,80 & 1,18 \\
\hline 0 & 11 & 10 & 10 & 10 & Austria & 0 & 8 & 26 & 20 & 54 & 0,00 & 0,23 & 0,81 & 0,66 & 0,51 \\
\hline 0 & 0 & 15 & 19 & 19 & Japan & 0 & 0 & 4 & 5 & 2 & 0,00 & 0,00 & 0,12 & 0,16 & 0,08 \\
\hline 0 & 0 & 0 & 17 & 21 & China & 0 & 0 & 0 & 7 & 7 & 0,00 & 0,00 & 0,00 & 0,23 & 0,07 \\
\hline 0 & 21 & 0 & 18 & 21 & South Korea & 0 & 1 & 0 & 6 & 7 & 0,00 & 0,03 & 0,00 & 0,20 & 0,07 \\
\hline & & & & & Other 43 countries & 3 & 45 & 90 & 145 & 283 & 0,35 & 1,27 & 2,78 & 4.75 & 2,65 \\
\hline & & & & & Total & 853 & 3515 & 3232 & 3050 & 10650 & 100 & 100 & 100 & 100 & 100 \\
\hline
\end{tabular}




\section{CONSTRUCTION OF A HIERARCHY OF CONTEMPORARY ART TERRITORIES BY INTERNATIONAL ART MAGAZINES FROM I97I TO $20 I 0$}

Which countries in the world attract the most contemporary art exhibitions according to the international art magazines? Which Asian countries are most favored by Western art magazines in terms of the organization of contemporary art exhibitions? What are the essential elements allowing for visibility of contemporary artwork and the interest of international journals? It is interesting to analyze and clarify certain geographical considerations linked to visual art exhibitions since the emergence of contemporary art in international media and, in particular, Western art magazines. If exoticism can be generated through a comparative context involving different cultures and territories, a geographical analysis will be relevant to unveil the global position of our three Asian countries in international contemporary art. It seems that no statistical analysis of the Review and Preview headings has been carried out to date, although such as an analysis provides us with very rich information and clues vis-à-vis many of the issues we have just raised.

Table I illustrates ten Western and three Asian countries ranked by the number of articles about them, and a comparison of these numbers. Note that almost all of the articles we counted for this empirical study came from Review and Preview ${ }^{30}$, which promote major and selected exhibitions by editors worldwide. Note also that the Review ran from the I980s for Flash Art, while the other three art magazines show growth in the visibility of contemporary art from the I970s onwards. The four decades of our research show that the visibility of the USA is always greatly highlighted in Art in America with 8,90I articles, which translates into 92.34 of the total number of articles. Artforum is also interested in the artistic and cultural activities organized in the USA, with I0,645 articles covering the USA, which represents $68.3 \mathrm{I}$ of the total. The visibility of the USA was markedly lower in the other two international magazines: Flash Art showed 39.6I visibility for the USA, with I,8I3 articles, and Artpress showed barely 5.02, with 535 articles. On the other hand, this last magazine demonstrates a substantial interest in France, with 7,888 articles comprising 74.07 of the total from I97I to 20I0. If we consider that Art in America and Artforum are edited in the USA and the head office of Artpress is located in France, we can see that these magazines have a strongly geocentric vision that massively favors the visibility of their own country. Notice also that the very high percentage of articles devoted to the USA in Art in America precludes the development of articles on other countries and the position of Flash Art seems neutral in comparison to the other three art journals.

From I97I to 20I0, other countries naturally demonstrate low visibility compared to the USA and sometimes France, but we can nevertheless cite some Western countries benefiting from a fairly remarkable visibility. First, Germany shows visibility from I.I2 (Art in America) to II.3 (Flash Art), and the UK remains between I.63 (Art in America) and I2.6I (Flash Art). These countries take between second and sixth place in the international ranking, in terms of the number of articles

30 Note that only the Artforum develops the Preview system. This rubric starts from 1990s. 
appearing in our four international art magazines. The position of France remains at almost the same level as these two European countries in Art in America ( 3 rd $/$ II 7 articles/I.2I), Artforum (4 $4^{\text {th }} / 597$ articles/3.83), and Flash Art (4th/5I2 articles/II.I9). Italy, Switzerland, the Netherlands, Austria, and Spain are always classed within the ten major countries in terms of number of articles, while Canada and Belgium are only partially quoted by the rubric Review/Preview of our four international art magazines. Note that only the ranking of the American art magazines represents Canada ( $8^{\text {th }}:$ Artforum; $9^{\text {th }}$ : Art in America), while only Artpress enhances the visibility of Belgium ( $5^{\text {th }}$ ) during the four decades of our research. In addition, if we consider that Canada, an English-speaking country, is situated near the USA, and Belgium, a French-speaking country, is located to the northwest of France, we can see how geographical proximity and the sharing of language can influence the visibility of contemporary art from particular locations.

Many sociologists, specialists, and historians of art have noted that the international contemporary art scene is dominated by Western countries, in particular by the USA ${ }^{3 \mathrm{I}}$. Our study on international art magazines underscores and confirms again this international optic, showing the hierarchical structure of the art world. However, we see that, in general, the proportional visibility of certain Western countries decreases from the I980s onwards, as globalization affects the field of contemporary art. If we compare the percentages only between the I980s and the 20Ios, the USA has a loss of 8 in both Artforum and Art in America, followed by a loss of I7 in Flash Art. As for France, its visibility is marked by a decrease of almost Io in Artpress and I2 in Flash Art. The falling visibility of these two countries in turn allows for the growth of others.

Therefore, the majority of our four art magazines reflect that our three Asian countries have become players in the international art scene since the beginning of the era of globalization. Japan was represented firstly by Art in America (I3 articles), Artforum (I9 articles), and Flash Art (II articles) in the I980s, competing with Western countries by placing among the top ten countries according to visibility in Art in America $\left(5^{\text {th }}\right)$ and Flash Art $\left(8^{\text {th }}\right)$ for the four decades of our research. Even China, which for a long time prohibited the development of contemporary art under the rule of Chairman $\mathrm{MaO}^{32}$, started to gain visibility from the I990s. It placed between $\mathrm{I}_{4}^{\text {th }}(\mathrm{Art}$ in America) and $23^{\text {rd }}$ (Artforum) during the four decades of our research. In the same

3I BYDLER, C. The Global Art World, inc: On the globalization of contemporary art. Stockholm: Acta Universitatis Upsaliensis, 2004; GRENIER, C. Modernités plurielles I905-I970. Paris: Musée National d’Art Moderne. Centre Pompidou, 20I4; GUILBAUD, S. Comment New York vola l'idée d'art moderne, op. cit.; MCANDREW, C. Globalisation and the art market: emerging economies and art trade in 2008., Maastrich:t The European Fine Art Foundation, TEFAF, 2009; MOULIN, R. L'artiste, l'institution et le marché, op. cit.; QUEMIN, A. La Chine et l'art contemporain..., op. cit.; QUEMIN, A. Montrer une collection internationale d'art contemporain: la place des différents pays sur les cimaises du Centre Pompidou, published. In: Trente ans d'histoire Centre Pompidou, Paris, 2007; QUEMIN, A. Les stars de l'art contemporain, op. cit.; SANDLER, I. Le triomphe de l'art américain: les années 60 Translated by Frank Straschitz. Tome 2. Carré (ed), I990; HEST, V. F. Territorial factors in a globalise dart world?, op. cit.

32 Napack, J. Young Beijing, Art in America, june-july, 2004, p. I42-I46. 
period, the visibility of Korea remains relatively low, occupying between $18^{\text {th }}$ (Art in America) and $32^{\text {nd }}$ (Flash Art) place, but it was mentioned in the I99os by three art magazines (Art in America, Artforum, and Flash Art) with II articles, while China only had, in the same period, one article, which was included in Artforum.

\begin{tabular}{|c|c|c|c|c|c|c|c|c|c|c|c|c|c|c|c|}
\hline \multicolumn{16}{|c|}{$\begin{array}{l}\text { Table } 2 \text { - Global position of } 9 \text { Latin America countries in four international } \\
\text { art magazines from } 1971 \text { to } 2010 \text { in terms of number of articles }\end{array}$} \\
\hline \multicolumn{5}{|c|}{ Ranking } & & \multicolumn{5}{|c|}{ Number of articles } & \multicolumn{5}{|c|}{$\%$} \\
\hline $\begin{array}{l}1971- \\
1980\end{array}$ & $\begin{array}{l}1981- \\
1990\end{array}$ & $\begin{array}{l}1991- \\
2000\end{array}$ & $\begin{array}{l}2001- \\
2010\end{array}$ & $\begin{array}{l}1971- \\
2010\end{array}$ & & $\begin{array}{l}1971- \\
1980\end{array}$ & $\begin{array}{l}1981- \\
1990\end{array}$ & $\begin{array}{l}1991- \\
2000\end{array}$ & $\begin{array}{l}2001- \\
2010\end{array}$ & $\begin{array}{l}1971- \\
2010\end{array}$ & $\begin{array}{l}1971- \\
1980\end{array}$ & $\begin{array}{l}1981- \\
1990\end{array}$ & $\begin{array}{l}1991- \\
2000\end{array}$ & $\begin{array}{l}2001- \\
2010\end{array}$ & $\begin{array}{l}1971- \\
2010\end{array}$ \\
\hline 0 & 19 & 17 & 14 & 16 & Brazil & 0 & 6 & 31 & 72 & 109 & 0,00 & 0,05 & 0,28 & 0,48 & 0,27 \\
\hline 11 & 21 & 21 & 20 & 18 & Mexico & 0 & 4 & 20 & 44 & 68 & 0,00 & 0,04 & 0,18 & 0,29 & 0,17 \\
\hline 0 & 0 & 22 & 22 & 24 & Argentina & 0 & 0 & 13 & 30 & 43 & 0,00 & 0,00 & 0,12 & 0,20 & 0,11 \\
\hline 0 & 0 & 31 & 43 & 37 & Venezuela & 0 & 0 & 6 & 4 & 10 & 0,00 & 0,00 & 0,06 & 0,03 & 0,02 \\
\hline 0 & 0 & 0 & 39 & 46 & Colombia & 0 & 0 & 0 & 6 & 6 & 0,00 & 0,00 & 0,00 & 0,04 & 0,01 \\
\hline 0 & 0 & 45 & 47 & 50 & Peru & 0 & 0 & 1 & 3 & 4 & 0,00 & 0,00 & 0,01 & 0,02 & 0,01 \\
\hline 0 & 0 & 0 & 43 & 50 & Chile & 0 & 0 & 0 & 4 & 4 & 0,00 & 0,00 & 0,00 & 0,03 & 0,01 \\
\hline 0 & 0 & 45 & 52 & 53 & Cuba & 0 & 0 & 1 & 2 & 3 & 0,00 & 0,00 & 0,01 & 0,01 & 0,01 \\
\hline 0 & 0 & 45 & 0 & 66 & $\begin{array}{c}\text { Dominican } \\
\text { Republic }\end{array}$ & 0 & 0 & 1 & 0 & 1 & 0,00 & 0,00 & 0,01 & 0,00 & 0,00 \\
\hline- & - & - & - & - & $\begin{array}{l}\text { Other } 67 \\
\text { countries }\end{array}$ & 3541 & 10929 & 10820 & 14911 & 40201 & 100,00 & 99,91 & 99,33 & 98,90 & 99,39 \\
\hline & & & & & Total & 3541 & 10939 & 10893 & 15076 & 40449 & 100 & 100 & 100 & 100 & 100 \\
\hline
\end{tabular}

We thereby confirm the emergence of our three Asian countries on the international contemporary art stage since the I980s, even if their visibility remains low. This result is greatly significant because the visibility of most non-Western countries mentioned by our four international art magazines increased in the same period as our three Asian countries ${ }^{33}$. Latin American countries are a good example, gaining more and more recognition in the field of contemporary art ${ }^{34}$. Table 2 shows that Brazil emerges first with Iog articles concentrated on it during the four decades of our research: I980s (6 articles), I990s (3I articles), and 2000s (72 articles). With an interval of $4 \mathrm{I}$ articles like Brazil, Mexico sees greater visibility from the I980s, while the other seven countries of the region only appear in our four international art magazine from the I990s. This result confirms that the last two decades of our research are the leading period of globalization in contemporary art if we limit

33 Note that the rubric Review/Preview of our four international art magazines mentioned 76 countries from I97I to 20I0. The territories of contemporary art become more and more diverse from the I980s. As for the development of the number of articles from 1970 to 2010, consult the note I5.

34 As we find in the exhibition Magicians of the Earth (1989). Consult notably the interview of Benjamin Buchloh with Jean-Hubert Martin (MARTIN, J.-H. Magiciens de la Terre, op. cit., p. 3I-46). The economic analysis proposed by Artprice 2013-20I4 well illustrates the integration of Latin American artists in the art market and well-known Western institutions spotlighting them, particularly artists from Brazil. 
ourselves to looking only at the peripheral countries. Note that the overall visibility of Latin American countries is very light (from 0.27 to 0.01 ) if we consider all of the countries mentioned by our four international art magazines. We indeed believe that this low visibility introduces the question of exoticism, which can be characterized by historicity, locality, nationality, specificity, singularity, identity, authenticity, and diversity, terms that have today become a matter of interest for many Brazilian intellectuals ${ }^{35}$.

By studying only three Asian artists as examples, we would like to know how peripheral countries attract the interest of international art magazines since the era of globalization. What is the esthetic value which allows non-Western countries to gain international visibility?

\section{EXOTICISM TRANSLATED INTO CLICHÉS AND STEREOTYPES IN INTERNATIONAL ART MAGAZINES}

This section proposes a concerted analysis of the three chosen East Asian countries through the articles devoted to their artists in our four international art magazines. A total of I,445 articles are collected during the 40-year timeframe, but we focus only on those exceeding more than one page. These articles are dedicated, in most cases, entirely to the presentation of one artist, developing concrete ideas and opinions about her, while the articles that take up less than a page - and are in most cases found in the Review/Preview - offer a simple description or information as an advertisement for an exhibition ${ }^{36}$. Note that our research on international rankings for contemporary art from the previous section is based on these types of articles. The 208 articles containing detailed ideas and points of view are therefore our main focus for understanding how Asian artists are described or represented in international magazines.

35 See the reactions of Roberto Conduru, Claudia Mattos, and Mônica Zielinsky to the reflections of Luiz Marques on the question: “Does Brazilian art exist?” (MARQUES, L.; CONDURU, R.; MATTOS, C.; ZIELINSKY, M. Does Brazilian art exist?, Perspective, article posted on June 30, 2015 and accessed on October oI, 2016. URL: http://perspective.revues.org/3879)

36 Among I,445 articles, we count I,237 which are one page or less in length. Despite little information about the artist and his creation, we may qualify 577 articles (47), almost all of which can be framed or understood by the three types of contextualization that we have proposed in Section 2. Study of the remaining I,237 articles could produce significant results, but we would like to focus on quality in regard to the information analyzed in our study. 


\begin{tabular}{|c|c|c|c|c|}
\hline \multicolumn{5}{|c|}{$\begin{array}{l}\text { Table 3-Growth in visibility of Japanese, Chinese, and Korean } \\
\text { artists in international art magazines from } 1971 \text { to } 2010\end{array}$} \\
\hline Decade & Country & Number of articles & $\begin{array}{l}\text { Number of articles with } \\
\text { clichés }\end{array}$ & $\%$ \\
\hline \multirow{4}{*}{$1971-1980$} & JP & 8 & 4 & 50 \\
\hline & $\mathrm{CN}$ & 1 & 1 & 100 \\
\hline & KR & 3 & 2 & 67 \\
\hline & Total & 12 & 7 & 58 \\
\hline \multirow{4}{*}{$1981-1990$} & $\mathrm{JP}$ & 22 & 12 & 55 \\
\hline & $\mathrm{CN}$ & 5 & 3 & 60 \\
\hline & KR & 4 & 4 & 100 \\
\hline & Total & 31 & 19 & 61 \\
\hline \multirow{4}{*}{$1991-2000$} & JP & 44 & 26 & 59 \\
\hline & $\mathrm{CN}$ & 15 & 12 & 80 \\
\hline & $\mathrm{KR}$ & 11 & 8 & 73 \\
\hline & Total & 70 & 46 & 66 \\
\hline \multirow{4}{*}{ 2001-2010 } & JP & 43 & 27 & 63 \\
\hline & $\mathrm{CN}$ & 38 & 30 & 79 \\
\hline & KR & 14 & 10 & 71 \\
\hline & Total & 95 & 67 & 71 \\
\hline \multirow{4}{*}{ 1971-2010 } & JP & 117 & 69 & 59 \\
\hline & $\mathrm{CN}$ & 59 & 46 & 67 \\
\hline & KR & 32 & 24 & 75 \\
\hline & Total & 208 & 139 & 67 \\
\hline
\end{tabular}

Table 3 was created using the long articles of the four art magazines from I97I to 20Io. Divided into four decades, it shows firstly the growth in the number of articles devoted to Japanese, Chinese, and Korean artists. The number of articles representing these artists through clichés and stereotypes is also included next to the total of number of articles. We can describe this type of presentation as "cliché/ article". When we consider all the results illustrated in the table, we notice that the cliché/article ratio is very high during the 40-year timeframe of our research. A total of I39 articles or 67 present Asian artists' work using stereotypical language, including "Samurai", "Sakura”, "Karaoke”, “Mao”, "Zen”, "Hiroshima”, etc. This single result indicates that Asian artists who are well known in international art magazines are likely very sensitive to their cultural and geographical background. We wonder if Western artists are as interested in their origins in their own artwork? Among the three East Asian countries, Japan remains in first place during the four decades in regard to the number of articles dedicated to it (I970s: 8, I980s: 22, I990s: 44, and 2000s: 43), while its percentage of clichés/articles is lower than the other two countries (I970s: 50, I980s: 55, I990s: 59, and 2000s: 63). If we consider that Japan is 
a country known for modern and contemporary artists such as Hokusai, L. Foujita, S. Arakawa, H. Sugimoto, T. Murakami, etc., it is possible to think that historical context is an important indicator for the international visibility of artists.

As for China, its visibility is only slightly ahead of Korea's as of the I990s, and then it increases sharply in the 2000 ( 38 articles). If we come back to the international rankings that we have studied, this "eruption of Chinese artists" 37 on the international contemporary art scene is also confirmed: China counts between 7 (Artpress) and I9 articles (Artforum) while Korea counts between 6 (Artpress) and I7 articles (Artforum) in the 2000s. We wonder if exoticism has played an important role in the growth of Chinese artists' visibility. Certainly, the proportion of clichés/articles has been significant during the last two decades: for China, 80 (I2 articles) and 79 (30 articles) of articles employ cliché(s) and stereotype(s) in the I990s and the 2000s, while Japan is marked by clichés/articles rate of less than 70 during the same period.

Korea saw a significant growth in the number of articles from the I990s onwards ${ }^{38}$, coinciding with the other two East Asian countries. This growth suggests that the I990s are, following the rapid development of peripheral countries seen in the 80 s, a turning point in globalization for Asian artists as seen by international Western magazines. As for the articles representing geographical identity, the proportion remains high in the I990s - more than 70 during the last three decades of our research. Note that articles containing cliché(s) and stereotype(s) increase gradually for the three East Asian countries during the four decades; I970s: 58, I980s: 6I I990s: 66, and 2000s: 7I. This result indicates that exoticism has increased in value during the era of globalization and that the Western world is looking more and more for "authentic" value ${ }^{39}$ in Asian artists.

How then do Asian artists known on the international art scene consider their artistic activities? Are they aware that their exoticism may influence their visibility in the international art scene, dominated as it is by Western countries? Do non-Western artists consciously try to introduce their geographical specificity through the use of clichés and stereotypes as an international strategy? To answer these questions, we next consider the discourse of some well-known Asian artists on the international contemporary art scene.

37 QUEMIN, A. La Chine et l'art contemporain..., op. cit., p. 77.

38 Note that the Gwangju Biennale in Korea was inaugurated in 1995.

39 We believe that the exoticism introduces the notion of rarity, originality and authenticity - terms that establish economic and esthetic value in contemporary art (MOULIN R. De la valeur de l'art. Paris Flammarion, I995; MOULIN, R. L'artiste, l'institution et le marché, op. cit.; HEINICH, N. Pour en finir... op. cit.). However, this value is different from exotic "beauty" generated by the unveiling of culture and civilization that we find, for example, in the expeditions of Victor Segalen in China done at the beginning of the $20^{\text {th }}$ century (SÉGALEN, V. Essai sur l'exotisme. Paris: Le Livre de Poche, I999). The terms “authentic" and "authenticity" that we employ in our research develop an important relation with a hedonistic attitude linked to tourism. We are indeed interested by “exotisme pacotille”, terms introduced and developed by Yves Michaud (MICHAUD, Y. L'art à l'état gazeux: essai sur le triomphe de l'esthétique. Paris: Hachette Littératures, 2003; MICHAUD, Y. La crise de l'art contemporain: utopie, démocratie et comédie. Paris: Presse universitaire de France, 2007). 


\section{TO BE VISIBLE AS PERIPHERAL ARTISTS IN THE INTERNATIONAL CONTEMPORARY ART WORLD}

Our preceding research unveiled the importance of exoticism, as represented by the usage of cliché and stereotype, through an empirical method based on the question of "diffusion". We now are interested in looking at the question of "creation", while linking it with the problematic imposed by the mass-media's usage today of a number of clichés and stereotypes. We propose a consideration of the speech of several Asian artists and their reactions in regard to the new paradigm imposed by the Western art world's aesthetic taste in a regime of pluralism. By consulting numerous websites that regularly broadcast artists' official statements or general ideas, we can discern the role and influence of exoticism in the creation of non-Western artists. This task first requires taking a selection of several representative Japanese, Chinese, and Korean artists using our research on our four international art magazines.

In our preceding research on our four international art magazines, we saw that the 2000s was the most prolific period for our three Asian countries (Japan: 43 articles, China: 38 articles, and Korea: 14 articles). We are particularly interested in this period not only for its explosion of Asian artists on the international art stage, but because it is the most current period among our four decades of research. For that reason, we now consider the discourses of three Asian artists interviewed in Art in America, Artforum, Flash Art, and Artpress between $200 \mathrm{I}$ and 2010.

\begin{tabular}{|c|c|c|c|c|c|c|c|}
\hline \multicolumn{7}{|c|}{ Table 4-Ten most visible Asian artists in the international art scene from 2001 to 2010, } \\
ranked by dedicated articles in international art magazines & $\begin{array}{c}\text { Number } \\
\text { of articles }\end{array}$ & EX“ & $\%$ \\
\hline Ranking & Country & Date of birth & Sexe & Name & 6 & 6 & 100 \\
\hline 2 & JP & 1962 & M & Takashi Murakami & 5 & 5 & 100 \\
\hline 3 & CN & 1957 & M & Ai Weiwei & 5 & 4 & 100 \\
\hline 3 & CN & 1957 & M & Cai Guo-Qiang & 4 & 3 & 75 \\
\hline 5 & KR & 1978 & F & Cao Fei & 4 & 3 & 100 \\
\hline 5 & JP & 1948 & F & Lee Bul & 3 & 3 & 67 \\
\hline 5 & CN/US & 1973 & M & Paul Chan & 3 & 0 & 0 \\
\hline 5 & KR & 1971 & F & Haegue Yang & 3 & 1 & 33 \\
\hline 5 & CN & 1971 & M & Yang Fudong & 3 & 3 & 100 \\
\hline 10 & KR & 1962 & M & Do Ho suh & 2 & 2 & 100 \\
\hline 10 & CN & 1954 & M & Huang Yong Ping & 2 & 2 & 100 \\
\hline
\end{tabular}

* Number of articles: only the number of articles exceeding more than one page.

** Number of articles containing cliché(s) and stereotype(s).

Table 4 shows the eleven Asian artists ranked most prominent on the international art stage in the 20oos. This ranking was established according to the 
number of articles dedicated to each artist in our international art magazines. Note that we also show the number of articles containing cliché(s) and stereotype(s), with the aim of discovering which artists have benefitted the most from possessing an air of exoticism. Looking at our four international magazines, edited only in the 2000 , Murakami ( 6 articles) is the best known Asian artist if we count only the articles that exceed more than one page. Ai Weiwei follows Murakami with 5 articles, followed by Cai Guo-Qiang ( 4 articles), Cao Fei ( 4 articles), etc. With 3 articles, Lee Bul is ranked first among Korean artists mentioned by our four international art magazines.

With an eye toward unveiling the role of exoticism in the creation of peripheral artists, consider now the discourse of Takashi Murakami, Ai Waiwai, and Lee Bul. They are respectively the top-ranked Japanese, Chinese, and Korean artists featured in our periodicals in the 20oos. We would like to establish if the artists themselves are aware of the issues raised here in regard to the geographical identity of their native land, and the possibility that it might enhance their visibility in the contemporary art world. Note that the major target of our study is the mass media, which since the beginning of globalization represents not only the work of Western artists but all the work of peripheral artists on the international art scene. For this reason, we are mainly interested in the artists' ideas, speeches, and statements circulating in the mass-media (websites, catalogues, art magazines, etc.). We will first introduce the texts on Takashi Murakami ${ }^{40}$, who has seen great international success since the 2000s, most notably in the art market. Note that this Japanese artist is represented by the Perrotin and Gagocian galleries ${ }^{4 \mathrm{I}}$, which allows us to obtain many "official” texts.

According to several articles and texts on Murakami's work, we can easily see that this artist is trying to speak about Japanese cultural specificity. He notably favors otaku, manga, Japanese traditional painting (nihonga), and the Japanese tragedies marked by the atomic bomb at the end of the Second World War ${ }^{42}$. Among all the articles looking at the exotic aspect of Murakami's work, the following excerpts summarize well his view of his place in the art world:

... I am jealous of Warhol. I'm always asking my design team, Warhol was able to create such an easy painting of life, why is our work so complicated? But history knows! My weak point

40 When we consider the annual report of Artprice, this Japanese artist ranked $8^{\text {th }}$ in the auctions conducted between 2008 and 2009.

4I Note that the role of the gallery is largely extended in the contemporary art world by helping artists to develop their careers as part of a durable relationship (HEST, V. F. Territorial factors in a globalisedart word?, op. cit., p. I68). To gather more information and texts about this Japanese artist, consult the official site of the Gagocian (http://www.gagosian.com) and Perrotin galleries (http://www.perrotin.com).

42 We would like to cite, as an example, an extract of that kind of article: 'Murakami believed that by incorporating the Japanese sub-culture into art, he could better depict the Japanese culture. Calling himself otaku, or a person who is obsessed with anime and cartoons, he creates sculptures and paintings that feature anime-inspired characters and elements of the Japanese traditional painting "nihonga”'. Lee, W-Y. With money and fame, Takashi Murakami has it all Prominent contemporary artist holds "petite" retrospective at Plateau, Samsung Museum of Art, with new works, The Korea Herald, July 3, 20I3. [Online] Available from: http://www. gagosian.com/artists/takashi-murakami/artist-press 
is my oriental background. Eastern flavor is too much presentation. I think it is unfair for me in the contemporary art battlefield, but I have no choice because I am Japanese ${ }^{43}$.

In those days, I was looking for a form that would express my originality, or, let's say, that would make my name, so that my works could be sold in the art world as I then perceived it. But what was my identity? The answer is that I didn't really have one. So I felt that the only thing I could do, to explain that absence of identity, was to pile up all the formative layers that had contributed to my background: for example, my work in the field of nihon-ga, the soldier figures that I used, my very marked taste for manga and for anime. I thought that by making all that clear, by showing how I had existed without any real identity. I would be able to start up something else. It was during the process of transformation, going from nihon-ga to contemporary art, that I came to against this problem: gradually, as I made more and more works, I realized that I didn't really have an identity ${ }^{44}$. [Translation]

Through these texts, we can see that Murakami is very interested in promoting the culture of his country, hoping to redefine or reinvent his identity through Japanese specificity. He freely uses the traditional elements of Japanese painting (nihonga) and Japanese cultural meaning (otaku). He is also conscious of the cultural limits imposed by his native land, as he testifies to here: 'My weak point is my oriental background. Eastern flavor is too much presentation. I think it is unfair.' For this artist who has had great success on the art market, identity and cultural originality can even facilitate the sale of his works: 'I was looking for a form that would express my originality, or, let's say, that would make my name, so that my works could be sold in the art world as I then perceived it. But what was my identity?' Note especially that Murakami, who thinks he has no real identity and is interested in selling his works, reinvents his cultural identity, while introducing nihonga, film animation, and manga into his work: 'I was looking for a form that would express my originality, or, let's say, that would make my name, so that my works could be sold in the art world as I then perceived it.'

As for Ai Weiwei, a Chinese artist known as an "activist", notably for protesting

43 THORNTON, S. Takashi Murakami on What is an artist?, an excerpt from Sarah Thornton's Seven Days in the Art World, 2009. This text is presented in the official site of Perrotin Gallery. [Online] Available from: https://www.perrotin.com/artists/Takashi_Murakami/I2\#id5Io

44 “À l'époque, je me demandais quelle forme d'expression adopter pour manifester mon originalité, ou, disons, pour me faire connaître, pour vendre mes œuvres dans le monde de l'art contemporain tel que je le percevais. J'étais en pleine quête d'identité. En fait, je n'en avais pas vraiment. J'ai alors cherché à expliquer cette absence d'identité en superposant toutes les étapes qui constituaient ma formation, mon background, mon travail dans le domaine du nihon-ga, l'utilisation des petits soldats, mon goût très prononcé pour les mangas, pour les films d'animation... En mettant tout à plat, en montrant comment, à travers ces différentes étapes, j'avais vécu sans identité, je pouvais passer à autre chose. C'est au cours du processus de transformation allant du nihon-ga à l'art contemporain que je me suis heurté à ce problème: au fil des œuvres que j'élaborais, je me rendais compte que je n'avais pas vraiment d'identité." MURAKAMI, T.; KELMACHTER, H. Takashi Murakami, edited on the occasion of the exhibition at Fondation Cartier pour l'art contemporain and Serpentine Gallery, Paris, London, 2002, p. 72. 
against the policies of Chinese authorities, he refers very regularly in his creative activities to Chinese patrimony and ancient dynastic traditions such as "calligraphy", "temples”, “Qing”, “Ming”, "Han”, “Tang”, etc. ${ }^{45}$ Among the many texts of his available on the Internet, an interview by Business Week China on the design of the Bird's Nest stadium in Beijing most aptly demonstrates that Ai Weiwei is aware of his identity as Chinese on the international art scene:

BWC: Some people are saying that you were the "Chinese consultant" to the foreign design firm; in this sense, are they saying that you brought Chinese elements to the design?

AWW: That is nonsense. In the process of design, we never once brought up any issue of alleged "Chinese elements". The reasoning is quite simple: I am a Chinese, and thus I possess reasoning and a mode of thinking that belongs to my native culture. When the design was finished, and before it was sent to the competition, they said they should identify some Chinese elements in it. At that time it was necessary, so we talked about cracked ice patterns in pottery glaze, or the patterns on ancient painted pottery, I'm very familiar with these. We talked about it in the proposal as well, a so-called "ordered chaos", and ideas such as "perfect vessels" which demonstrate an understanding of the ancient Chinese classics. These were just to aid in identifying a pretext ${ }^{46}$.

Ai Weiwei expresses here his awareness of his cultural origins and critiques the absurdity of the reasoning that being Chinese introduces naturally Chinese cultural elements to his art work. Western critics seemingly try to understand peripheral artists via "specific codes" which "distinguish a given place from all others on the international tourist map'.

For Lee Bul, we have studied several texts and interviews available online. The majority of these do not contain any clear clichés and stereotypes, but we see that Ioo of the articles devoted to this Korean female artist discuss exotic aspects of her art. Our four international art magazines use several stereotyping keywords, including "Karaoke”, "PC bang", "Asian ceramics", "Asian history", "traditional material”, etc. Below are some extracts from the articles and interviews devoted to this artist:

45 [Online] Available from: http://aiweiwei.com/ [Accessed: 20I7]. [Online] Available from: http://www. lissongallery.com/artists/ai-weiwei [Accessed: 20I7]; [Online] Available from: http://maryboonegallery. com/exhibitions/20II-20I2/Ai-Weiwei/gfx/WEIWEI2opress2orelease.pdf [Accessed: 20I7]; SMITH, K.; ULRICH OBRIST, H.; FIBICHER, B. Ai Weiwei. New York: Phaidon, 2009, p. I6-I9; HASKI, P. La vie sous surveillance: rencontre avec Ai Weiwei à Pékin. nov. 3., 2013. [Online] Available from: http://rue89.nouvelobs. com/2013/II/03/vie-sous-surveillance-rencontre-lartiste-ai-weiwei-a-pekin-247I62 [Accessed: 20I7]

46 WEIWEI, A. Ai Weiwei's Blog: Writings, interviews and Digital Rants, 2006-2009. Edited and translated by Lee Ambrozy. Cambridge: The MIT Press, 20II, p. I63-I64. 
... skillfully manipulated cultural clichés, simultaneously spoofing Western images of the exotic Asian woman and expectations of how Eastern feminist art should look ${ }^{47}$.

How do you think your female/Asian background effects your relationship with international curators and critics? It seems ironic that your recent sculptures of cyborg parts look futuristic despite their being made of porcelain, the most traditional material in Korean art. Actually, pottery-making techniques, especially advancements in ceramics, constituted a very 'high technology' in Asian history. Despite common perceptions porcelain is an extremely durable, heat-resistant material, and certain types of ceramics are used today, in space crafts and special engines. So are Asian ceramics really a sign of the traditional? ${ }^{48}$

These extracts demonstrate that Lee Bul uses her own artistic language when speaking about Asian clichés aimed at a Western audience. This audience, according to Lee Bul, is constantly trying to understand artwork through the artist's "female/ Asian background". The appreciation of the peripheral artist's work relies on an empirical system and mechanism of interpretation created by the Western artistic viewpoint. Lee Bul's works are then the fruits of the tension between Western and non-Western culture, meaning that she is very conscious of her identity as Korean, using many cultural symbols from her native country.

This Koreanity has indeed likely helped her on the international art scene, if we consider that Lee Bul was awarded a Special Mention on the occasion of the $48^{\text {th }}$ Venice Biennale (I999) for her Live Forever futuristic installation, involving essentially soundproof karaoke. We cite again the exhibition organized by the Cartier Foundation in 2008 that considered the cultural relativity between Western and Korean society and politics. This featured both Baekdu, a sacred mountain for Korean people, as well as modern Korean history marked by General Park Chung-hee, who is considered to have been at the same time a dictator and a national hero for reviving the country's economy. Afterwards, Lee Bul said, 'The mystical components of the utopias of the East and the West are met here, at least in a reflection ${ }^{49}$.

It is true that Lee Bul's work is less interested in the question of national identity or Korean culture compared to the other Asian artists we have considered above. However, we can say that she does constantly give a Korean specificity to her artwork. The West, in turn, tries to understand her art though clichés and stereotypes ${ }^{50}$.

47 Art in America, may, 2002, p. I24-I27.

48 Art in America, jan.-feb., 200I, p. 64.

49 LEE, B. On every new shadow (catalogue of exhibition). Paris: Fondation Cartier pour l'art contemporain, 2007 , p. 67.

50 Note that cliché and stereotype influence aesthetic value even in the creation of Western artists, as Olafur Eliasson testifies. This Danish artist who spent his childhood in Iceland and currently lives in Germany is considered by the German public as a “typically Scandinavian” artist. (GRYNSZTEJN, M. Olafur Eliasson (catalogue). Paris: Phaidon, 2007, p. 32-33.) 


\section{ConClusion}

Among our four international art magazines, contemporary art is dominated by particular Western countries, notably the USA from I97I to 20I0. However, the visibility of non-Western countries has risen progressively in the media since the era of globalization. Japan, China, and Korea, peripheral countries that we have selected as examples, have made their presence known on the international art scene from the I990s onwards, even if very few articles are devoted to these countries compared to Western countries.

We have found that many articles on artists from our three Asian countries reinforced clichés and stereotypes by developing exotic language that attempts to aid Western criticism's understanding of artworks from a far-off country. Exoticism acts as a new aesthetic criterion, revealing a substantial relationship between clichés based on the geographical, cultural, ethnic, and sometimes religious origin of the artist, as well as their visibility on the international art scene. The West therefore requires non-Western artists to invent their own artistic narrative linked to their country of origin. Artists promoting their differences have a greater chance of being recognized on the international art scene if they use clichés and stereotypes, which facilitate communication and understanding of the culture of "exotic" countries. Clichés and stereotypes act as a means for translating the exotic culture, language, and history of far-off countries into a universal vocabulary, referencing both tourism and aesthetics. For this reason, peripheral artists often create and invent a kind of communication strategy designed specifically for the West's tastes, while taking advantage of the mass-media experience. To be "exotic" often assists, encourages, and promotes the work of non-Western artists in the form of kitsch, which then appears authentic, specific, and original in international contemporary art. Exoticism reincarnates the myth of originality, authenticity, and artistic uniqueness, and strengthens the capitalist system because "rarity" ensures high economic and artistic value. Note that "to be exotic" is not simply a question of aesthetic taste in regard to Asian countries; it also, in the end, raises the issue of the artistic freedom of peripheral artists condemned today to speak almost only of their ancestors. 
KUSUK YUN obteve o seu doutorado (PhD) da Universidade Paris VIII - Vincennes - Saint Denis em 2016 sob a direção de Alain Quemin com a tese intitulada To be exotic in contemporary art: The international art scene and three Asian countries - Japan, South Korea and China - in an era of globalization. De 2015 a 20I8, dirigiu Educação e Marketing para o Suwon Ipark Museum e organizou inúmeras exposições de arte contemporânea e programas educacionais. Trabalha como pesquisador no Asia Culture Institute, com sede em Gwangju City, na Coreia do Sul.

\section{BIBLIOGRAPHY}

BENJAMIN, W. L'œuvre d'art à l'époque de sa reproductibilité technique. Version de I939. Paris: Gallimard, 2007.

BYDLER, C. The global art world. Inc: On the globalization of contemporary art. Stockholm: Acta Universitatis Upsaliensis, 2004.

CLIFFORD, J. The predicament of culture: twentieth-century ethnography, literature, and art. Cambridge: Harvard University Press.). I988.

EHMANN, T. The Artprice annual report. 2006/2007 - 2015/2016. Lyon: Artprice, 2009.

GARRETA, V. (Dir.). Pour une nouvelle géographie artistique des années 90. Bordeaux: CAPC Musée d'art contemporain de Bordeaux, 200 .

GLICENSTEIN, J. L'art: une histoire d'expositions. Paris: Presses Universitaires de France, 2009.

GRENIER, C. Art et mondialisation: anthologie de textes de 1950 a nos jours. Paris: Centre Pompidou. 2013. . Modernités plurielles I905-I970. Paris: Musée National d’Art Moderne. Paris: Centre Pompidou, 20I4.

GRYNSZTEJN, M. Olafur Eliasson (catalogue of exhibition). Paris: Phaidon, 2007.

GUILBAUD, S. Comment New York vola l'idée d'art moderne: expressionnisme abstrait. liberté et guerre froide. Nîmes: Jaqueline Chambon. I998.

HEINICH, N. Pour en finir avec la querelle de l'art contemporain. Paris: L’Echoppe. I999.

. De la visibilité: Excellence et singularité en régime médiatique. Paris: Gallimard, 2012.

HEST, V. F. Territorial factors in a globalized art world? The visibility of countries in international contemporary art events. Rotterdam: ERMeCC, $20 \mathrm{I2}$.

LEE, B. On every new shadow (catalogue of exhibition). Paris: Fondation Cartier pour l'art contemporain, 2007.

MARTIN, J.-H. L'Art au large. Paris: Flammarion, 2012. . Magiciens de la Terre (catalogue of exhibition). Paris: Musée National d'Art Contemporain, I989.

MCANDREW, C. Globalisation and the art market: emerging economies and art trade in 2008. Maastricht: The European Fine Art Foundation. TEFAF, 2009. 
MICHAUD, Y. L'artiste et les commissaires: quatre essais non pas sur l'art contemporain mais sur ceux qui s'en occupent. Paris: Hachette Littératures, 2007. (collection Pluriel).

. La crise de l'art contemporain: utopie. démocratie et comédie. Paris: Presse universitaire de France, I997.

. Critères esthétiques et jugement de goût. Paris: Jacqueline Chambon, I999.

. L'art à l'état gazeux: essai sur le triomphe de l'esthétique. Paris: Hachette Littératures, 2003.

MILLET, C. D'artpress à Catherine M. Entretiens avec Richard Leydier. Paris: Gallimard, 20II.

. L'Art contemporain: Histoire et géographie. Paris: Flammarion , 2006.

MOULIN, R. L'artiste, l'institution et le marché. Paris: Flammarion, I997.

. De la valeur de l'art. Paris: Flammarion, I995.

MOURA, J.-M. La littérature des lointains: Histoire de l'exotisme européen au XX $\mathrm{XX}^{\mathrm{e}}$ siècle. Paris: Honoré Champion, I998.

. Lire l'exotisme. Paris: Dunod, I992.

MURAKAMI, T.; KELMACHTER, H. Takashi Murakami. Edited on the occasion of the exhibition at Fondation Cartier pour l'art contemporain and Serpentine Gallery. Paris. London, 2002.

OLIVA, A. B.; GU, D.; MAGGIO, G. D.; FEI, D.; KIM, S.-D. Asiana: Contemporay Art from Far East. Edited on the occasion of the exhibition at the Palazzo Vendramin Calergi. Milan: Fondazione Mudima in cooperation with Venice Municipality the Cultural Council, I995.

QUEMIN, A. Le rôle des pays prescripteurs sur le marché et dans le monde de l'art contemporain. Paris: Rapport au ministère des affaires étrangères, 2001.

. L'art contemporain international: entre les institutions et le marché. Paris: Jacqueline Chambon/ Artprice, 2002.

. L'illusion de l'abolition des frontières dans le monde de l'art contemporain international: La place des pays "périphériques" à "l'ère de la globalisation et du métissage". Paris: Université de Marne-la-Vallée, 2002. . Les Stars de l'art contemporain. Paris: CNRS, 2013.

SANDLER, I. Le triomphe de l'art américain: les années 60. Translated by Frank Straschitz. Tome 2. Carré (ed.), I990.

SEGALEN, V. Essai sur l'exotisme. Paris: Le Livre de Poche, I999.

SMITH, K.; ULRICH OBRIST, H.; FIBICHER, B. Ai Weiwei. New York: Phaidon, 2009.

STRÖTER-BENDER, J. L'art contemporain dans les pays du "Tiers monde". Translated by Olivier Barlet. Paris: L'Harmattan, I99I.

THORNTON, S. Seven days in the art world. New York: W. W. Norton \& Company, 2009.

TODOROV, T. Nous et les autres: la réflexion française sur la diversité humaine. Paris: Seuil, I989.

WEIWEI, A. Ai Weiwei's Blog: writings. interviews and digital rants. 2006-2009. Edited and translated by Lee Ambrozy. Cambridge: The MIT Press, 20II.

\section{ARTICLES}

CAVALCANTI, P.; SIMIONI, A. Des diasporas du moderne: les artistes brésiliens à Paris dans les années I920. Art et société. Marseille: OpenEdition Press, 2016.

GROYS, B. The Global Issue: a symposium. Art in America, New York, july I989.

HASKI, P. La vie sous surveillance: rencontre avec Ai Weiwei à Pékin. nov. 3, 2013. 
JOYEUX-PRUNEL, B. L'internationalisation de la peinture avant-gardiste. De Courbet à Picasso: un transfert culturel et ses quiproquos. Revue historique. Presses Universitaires de France, 2007/4 n. 644 . LINVILLE, K. Sonsbeek: speculations. impressions. Art in America. Oct., I97I.

MARQUES, L.; CONDURU, R.; MATTOS, C.; ZIELINSKY, M. Does Brazilian art exist?. Perspective, 20I3. [Online]. 2 | 20I3. Posted on June 30, 20I5. Accessed on October OI, 20I6. URL: http://perspective. revues.org/3879.

NAPACK, J. Young Beijing. Art in America. june-july, 2004.

MOTHERWELL, R. I4 Americans. Dorothy Miller. MOMA. New York. I946.

MORRIS, R. The art of existence: three extra-visual artists: works in process. Art in America, jan. I97I.

PINCUS-WITTEN, R. Christopher Wilmarth: a note on pictorial sculpture. Art in America, may. I97I.

PINCUS-WITTEN, R. Eva Hess: post-minimalism into sublime. Art in America, nov. I97I.

QUEMIN, A. La Chine et l'art contemporain: l'arrivée de l'Empire du Milieu dans le monde et sur le marché de l'art. In: BRET, J.-N. et MOUREAU, N. (Dir.). L'art. l'argent et la mondialisation. Paris.: L'Harmattan, 2013.

. Montrer une collection internationale d'art contemporain: la place des différents pays sur les cimaises du Centre Pompidou. article published in Trente ans d'histoire Centre Pompidou. Paris, 2007. RICHAUDEAU, F. La culture des mass media. Communication er Langages, $\mathrm{I}_{4}^{\circ}$, I972.

TUCHMAN, P. An interview with Robert Ryman. Art in America, may. I97I.

\section{SELECTED INTERNET SITES}

DAWEI, F.; GUO-QIANG, Cai. To dare to accomplish nothing. Thames \& Hudson et Fondation Cartier pour l'art contemporain. Londres, 2000 [Online] Available from: http://www.caiguoqiang. com/pdf/interviews/cartierbook.interview.fei.lo.pdf.

LEE, W.-Y. With money and fame. Takashi Murakami has it all Prominent contemporary artist holds 'petite' retrospective at Plateau. Samsung Museum of Art. with new works. The Korea Herald. July 3, 20I3. [Online] Available from: http://www.gagosian.com/artists/ takashi-murakami/artist-press.

http://www.perrotin.com

http://www.gagosian.com

http://aiweiwei.com

http://www.lissongallery.com/artists/ai-weiwei

http://rue89.nouvelobs.com/2013/II/03/

vie-sous-surveillance-rencontre-lartiste-ai-weiwei-a-pekin-247162

http://maryboonegallery.com/exhibitions/20II-20I2/Ai-Weiwei/gfx/WEIWEI\%20press\%20 release.pdf

https://www.centrepompidou.fr/media/document/76/oc/760c508854506430ofdr3242e9332aco/ normal.pdf 


\section{SELECTEd InTERnAtional ART MagaZines}

Art in America, I979, Jan. Feb.

Art in America, I985, Jan.

Art in America, I995, Oct.

Art in America, 200I, Jan.-Feb.

Art in America, 2002, May.

Artpress, 2007, Feb.

Flash Art, 2008, may.Jul,

Flash Art, I970, I7 Apr./Mar.

Flash Art, I993, Oct.

Artforum, I980, Apr. 